Insignia Journal of International Relations

Vol. 6, No.2, November 2019, 83-93

P-ISSN: 2089-1962; E-ISSN: 2597-9868

\title{
Diplomasi Lingkungan Hidup Indonesia-Norwegia Melalui REDD+ Agreement
}

\author{
Pramesthi Cahyani Hedhi Ningsih \\ London School of Public Relations Jakarta \\ Email: hedhipramesti@gmail.com
}

\begin{abstract}
Abstrak
Seiring meningkatnya kesadaran masyarakat dunia mengenai pentingnya menjaga kelestarian bumi, isu lingkungan hidup menjadi salah satu isu yang patut untuk dibicarakan di tingkat internasional, hal ini disebabkan oleh diperlukannya usaha dari berbagai pihak untuk menyelesaikan isu ini. Deforestasi dan degradasi lahan yang diakibatkan oleh aktivitas manusia, merupakan isu penting dalam lingkungan hidup yang selalu diperhatikan dari dunia internasional. Indonesia sebagai salah satu negara yang memiliki hutan tropis yang sangat luas di dunia yang dengan tegas menunjukkan komitmennya untuk menekan laju emisi yang dihasilkan. Komitmen Indonesia dilihat sangat strategis oleh Norwegia sebagai negara yang peduli akan lingkungan hidup, sehingga disepakati kerja sama internasional antara kedua negara melalui REDD+ agreement. REDD+ memiliki tujuan utama dalam mengurangi emisi yang dihasilkan oleh deforestasi dan degradasi hutan yang terjadi di Indonesia. Penelitian ini menggunakan metode kualitatif dan melihat bagaimana proses diplomasi lingkungan hidup yang dilakukan Indonesia-Norwegia dalam menjalankan REDD+ agreement, yang dikaji menggunakan 6 kunci elemen diplomasi. Hasil penelitian menunjukkan bahwa kerja sama REDD+ Indonesia-Norwegia telah berjalan dengan baik, atas dasar kepentingan nasional kedua negara dan dilihat bahwa REDD+ mengalami keterlambatan dalam mencapai target yang telah ditentukan untuk dipenuhi pada tahun 2016, hal ini dikarenakan oleh Indonesia belum mampu memenuhi syarat yang diberikan Norwegia untuk mendirikan institutional set up. Bagaimanapun, Indonesia dan Norwegia tetap melanjutkan kerjasamanya untuk mencapai target yang telah disepakati sampai benar-benar tercapai.
\end{abstract}

Kata Kunci: diplomasi lingkungan hidup, isu lingkungan hidup, REDD+

\begin{abstract}
As global public awareness towards the importance of maintaining earth sustainability is increasing, environmental issues become one of the interesting issues to be discussed at the international level. Deforestation and land degradation caused by emissions produced by human activities, is one of the important issues in the environment. Indonesia as a country with the third largest tropical forest in the world, strongly indicating commitment to reduce its emissions. This commitment was considered as a strategic movement by Norway, as a country that cares about the environment. Thus, both parties are agreed to create international collaboration through REDD + agreement. REDD + aims to reduce emissions generated by deforestation and forest degradation. This study used qualitative method and seeked at how Indonesia and Norway environmental diplomacy in running REDD + agreement was assessed using the 6 key elements of diplomacy. The results of this study showed that Indonesia and Norway REDD+ cooperation is running well on the basis of both national interests, however REDD+ experienced delay in achieving the determined target that supposed to be completed by 2016, due to Indonesia inability to meet Norway's requirements to establish institutional set up. Nevertheless, Indonesia and Norway keep maintaining their collaboration until all their mutual targets are fully achieved.
\end{abstract}

Keywords: environmental diplomacy, environmental issues, REDD+ 


\section{PENDAHULUAN}

Meningkatnya suhu bumi yang disebabkan oleh gas efek rumah kaca didorong oleh terjadinya deforestasi dan degradasi hutan. Sebagai negara yang kaya akan hutan hujan tropis, Indonesia juga mengalami deforestasi dan degradasi hutan. Hal ini membuat Indonesia sebagai salah satu negara yang banyak menyumbang gas emisi ke atmosfer. Berita yang dipublikasikan oleh REDD (Reducing Emissions from Deforestation and Forest Degradation) mengenai luasnya hutan hujan tropis di Indonesia menunjukkan: "Indonesia memiliki lahan hutan hujan tropis terbesar ketiga di dunia, dengan 68\% daratannya sama dengan 131.3 juta hektar, tertutupi oleh hutan (Kementerian Kehutanan, 2012). Tingkat deforestasi di Indonesia sangat tinggi, dengan angka yang diperkirakan mencapai 1.17 juta hektar per tahun (Pemerintah Indonesia dan UNREDD, 2009). Sebuah laporan pada tahun 2010 menunjukkan bahwa $85 \%$ dari emisi gas rumah kaca Indonesia berasal dari aktivitas penggunaan lahan; dengan 37\% karena deforestasi dan 27\% karena kebakaran gambut (Dewan Nasional Perubahan Iklim, 2010; The REDD Desk, n.d.)

Kemudian, pernyataan di atas didukung dengan artikel yang dipublikasikan oleh Zee News yang menyatakan bahwa, Indonesia merupakan negara penghasil minyak kelapa sawit terbesar di dunia dan juga salah satu produsen utama dari kertas dan kayu, yang berarti industri yang bersama melakukan penebangan pohon, sehingga menjadikan Indonesia penghasil emisi karbon dioksida terbesar ketiga (Zee News India, 2014)

Sebagai negara dengan luas hutan hujan tropis terbesar ketiga dunia, menjadikan Indonesia memiliki kontribusi yang sangat besar bagi kelangsungan hidup manusia di bumi. Dengan melindungi hutan hujan tropis Indonesia, sama artinya dengan menekan atau bahkan menghentikan perubahan iklim dunia. Penghancuran dan degradasi hutan memberikan pengaruh besar terhadap perubahan iklim dalam dua hal. Pertama, perambahan dan pembakaran hutan melepaskan karbon dioksida ke atmosfer. Kedua, kerusakan hutan akan mengurangi area hutan yang menyerap karbon dioksida. Kedua hal ini sangat penting karena jika hutan hujan tropis yang tersisa dihancurkan, maka manusia akan kalah dalam pertarungan menghadapi fenomena perubahan iklim (Novis, 2009: 3)

Pentingnya peran lingkungan hidup bagi kehidupan manusia, menciptakan sebuah kesadaran bagi masyarakat dunia. Dengan berbagai masalah dan tantangan yang dihadapi oleh berbagai negara membuat topik ini diangkat ke forum internasional Perserikatan Bangsa Bangsa (PBB) pada Konferensi Stockholm, di Swedia yang diselenggarakan pada tanggal 5-6 Juni 1972.

Kesadaran yang terbentuk di masyarakat dunia mengenai pentingnya menjaga lingkungan hidup membuat dilakukannya diplomasi lingkungan hidup dengan melibatkan peran serta masukan dari berbagai aktor internasional yang berasal dari aktor negara maupun bukan negara. Upaya penanggulangan kerusakan lingkungan hidup secara internasional dilakukan dalam bentuk diplomasi lingkungan hidup, salah satu contohnya adalah Indonesia dan Norwegia yang melakukan kerjasama diplomasi lingkungan hidup dengan upaya penurunan emisi yang disebabkan oleh deforestasi dan degradasi lahan dalam bentuk REDD+ Agreement .

Indonesia-Norwegia berkomitmen untuk memenuhi kerja sama bilateral khususnya dalam bidang lingkungan hidup melalui REDD+ Agreement disaat yang bersamaan dengan COP di Cancun melalui Letter of Intent (LoI) yang diajukan oleh Indonesia yang menunjukkan komitmennya untuk mengurangi emisi yang dilepaskan ke udara. LoI ini disambut baik oleh Norwegia. Kedua negara berkomitmen untuk terus mendorong kerja sama dalam rangka mengurangi efek perubahan iklim, yang salah satunya adalah mengurangi efek 
kebakaran lahan gambut (Kementerian Luar Negeri RI, 2016).

Penelitian ini dilakukan untuk mengetahui bagaimana diplomasi lingkungan hidup dilaksanakan dalam implementasi REDD+ Agreement Indonesia Norwegia. Berdasarkan latar belakang yang telah dipaparkan di atas, rumusan masalah dalam penelitian ini adalah Bagaimana diplomasi lingkungan hidup yang dilakukan Indonesia dan Norwegia melalui implementasi REDD+ Agreement? Pertanyaan ini penting dalam rangka untuk mengetahui gambaran deforestasi dan degradasi hutan yang terjadi di Indonesia. Kemudian untuk mengetahui dan menganalisis diplomasi lingkungan hidup yang dilakukan oleh Indonesia-Norwegia melalui REDD+ Agreement.

\section{Tinjauan Literatur}

Timbulnya kesadaran masyarakat dunia mengenai pentingnya permasalahan lingkungan menciptakan diplomasi lingkungan dalam lingkup internasional untuk mencari solusi bersama untuk menangani permasalahan ini.

Borg (dalam Pramudianto, 2011: 26), mendefinisikan pengertian diplomasi lingkungan hidup, "sebagai keterampilan dalam menangani masalah lingkungan, yang implikasinya disengaja dalam cakupannya". Definisi lain mengenai diplomasi lingkungan hidup juga didefinisikan oleh Pramudianto, yang berbunyi: "ilmu dan seni yang mempelajari dan menangani isu-isu lingkungan hidup untuk mencapai kesesuaian dengan kepentingan nasional (atau kepentingan dan kebijakan entitas bukan negara) terutama kebijakan politik luar negeri dan politik dalam negeri dibidang lingkungan hidup suatu negara". (Pramudianto, 2011: 28)

Untuk mempertajam analisis penelitian ini, peneliti menggunakan elemen kunci diplomasi menurut Paul Webster Hare (2015: 5), dia menyebutkan ada enam elemen kunci yang mempengaruhi aktivitas diplomasi. Elemen tersebut dijabarkan sebagai berikut. Pertama, para pihak yang terlibat dalam diplomasi tidak mewakili diri mereka sendiri. Mereka terlibat dalam pekerjaan sebagai wakil negara berdaulat. Kedua, diplomasi membutuhkan dua pihak atau lebih, dan pihak-pihak ini tidak mewakili entitas atau pemerintah yang sama. Ketiga, perlu ada kemauan dan sarana untuk berkomunikasi antar pihak. Ini menciptakan sebuah hubungan yang akan dibangun melalui kepercayaan dan akan dipandang hubungan yang berharga. Keempat, sifat hubungan biasanya adalah dilakukan secara terus menerus, tidak kaku, dan membutuhkan akses sepanjang waktu. Apapun yang terjadi, berapapun banyaknya darah yang telah tertumpahkan, dapat dipertaruhkan secara aman bahwa metode diplomatik cepat atau lambat akan dibangkitan kembali. Kelima, isi hubungan tidak dibatasi oleh definisi universal tentang apa yang diizinkan. Masing-masing pihak mendefinisikan apa yang dilihatnya menarik untuk terlibat dalam diplomasi. Keenam, semua pihak mungkin berusaha melibatkan setiap aktor dalam diplomasi mereka, siapa yang mungkin atau mungkin bukan merupakan entitas negara.

$$
\text { Pramudianto (2011: }
$$
menjelaskan bahwa kajian dalam diplomasi lingkungan hidup ada komponen penting yang dapat dilihat dari struktur kelembagaan, proses dan agenda yang dilaksanakan melalui diplomasi lingkungan hidup. Pertama, mengenai kelembagaan diplomatik suatu negara. Misi dan pejabat diplomatik merupakan perwakilan dan diplomat resmi suatu negara, yang memiliki peran penting dalam usaha meningkatkan hubungan persahabatan bagi kedua negara, terutama dalam menjalankan kepentingan nasionalnya. Kedua, proses diplomatik merupakan proses pembentukkan perjanjian internasional. Salah satu upaya yang dilakukan untuk meningkatkan kerjasama internasional adalah dengan melakukan perjanjian internasional. Proses pembentukkan perjanjian internasional dilakukan melalui beberapa tahapan seperti 
pra negosiasi, negosiasi, adopsi, dan penandatanganan, serta ratifikasi. Kemudian, setelah semua proses dilakukan, pelaksanaan atas perjanjian dilanjutkan melalui berbagai pertemuan yang merupakan proses pemantauan dan pengawasan.

\section{Metode Penelitian}

Penelitian ini menggunakan metode penelitian kualitatif deskriptif. Penelitian deskriptif bertujuan memberikan gambaran secara sistematis dan akurat mengenai suatu situasi atau area populasi tertentu yang bersifat faktual.

Untuk mendapatkan informasi pada penelitian ini maka dibutuhkan narasumber atau informan untuk memberikan informasi yang akurat. Informan yang akan diwawancara dalam penelitian ini adalah : (1) Ita Irawati Murjani, selaku Forest Advisor at The Royal Norway Embassy. Posisi yang dijabat oleh narasumber dapat memperkuat data penelitian yang ingin didapatkan dikarenakan beliau turun langsung ke lapangan dalam pelaksanaan REDD+; (2) Novia Widyaningtyas, selaku Kepala Sub Direktorat REDD+, Direktorat Mitigasi Perubahan Iklim, Ditjen PPI Kementerian Lingkungan Hidup dan Kehutanan. Narasumber ini dipilih karena memiliki data-data yang kuat dan valid terkait implementasi REDD+Agreement; (3) Muhsin Syihab, selaku Direktur Pembangunan Ekonomi dan Lingkungan Hidup, Kementerian Luar Negeri Indonesia. Narasumber dipilih karena memiliki datadata yang valid dan kuat terkait diplomasi yang dilakukan oleh Indonesia-Norwegia melalui REDD+ Agreement; (4) Yuyun Indradi, selaku Political Advisor Greenpeace Indonesia. Narasumber merupakan pengamat dan penasehat politik Greenpeace Indonesia yang bisa memberikan informasi yang akurat terhadap pelaksanaan REDD+ Agreement Indonesia-Norwegia.

Penelitian ini menggunakan teknik pengumpulan data yang dilakukan dengan cara memperoleh data oleh berbagai cara, khususnya melalui wawancara dan studi pustaka. Penelitian ini dilaksanakan dari bulan September 2017 sampai dengan bulan Juni 2018. Penelitian ini dilakukan di Jakarta, yaitu di Kantor Kementerian Lingkungan Hidup dan Kehutanan, Universitas Indonesia, Kedutaan Norwegia, dan Kementerian Luar Negeri RI.

\section{PEMBAHASAN \\ Diplomasi Lingkungan Hidup Indonesia- Norwegia: REDD+Agreement}

Diplomasi lingkungan hidup yang dilakukan oleh Indonesia-Norwegia melalui REDD+ Agreement dianalisis menggunakan enam kunci elemen diplomasi menurut Paul Webster Hare (2015). Dalam kerja sama lingkungan hidup ini, pihak yang terlibat adalah negara Indonesia dan Norwegia yang mewakili kepentingan negara masingmasing. Kepentingan Indonesia dalam REDD+ Agreement adalah menunjukkan komitmennya atas kesadaran yang dimiliki untuk menjaga lingkungan hidup karena Indonesia menyadari bahwa peran yang dimainkan oleh Indonesia bagi dunia sangat besar. Sebaliknya, Norwegia juga memiliki kepentingan untuk menjadi negara champion dalam penanganan isu lingkungan hidup, sehingga dengan menjadi pendonor dana kepada Indonesia, Norwegia mendapatkan citra positif di mata internasional.

Indonesia dan Norwegia dipertemukan dalam agenda COP (Conference of the Parties), sehingga COP merupakan sarana komunikasi awal mulanya diusulkan skema REDD+ Agreement. Kemudian, dengan adanya kerja sama yang dijalin, hubungan Indonesia-Norwegia dalam upaya penanganan masalah lingkungan hidup terus dilanjutkan. Kedua negara juga semakin giat untuk mencapai kepentingan nasionalnya walaupun ada tantangan yang harus dilewati. Pelaksanaan REDD+ Agreement tentunya tidak dapat hanya dilakukan oleh pemerintah saja, dibutuhkan bantuan aktor non-negara seperti United Nations Development Program (UNDP) dan 
Kemitraan untuk mempermudah pemerintah dalam pelaksanaan REDD+ Agreement.

Paul Webster Hare (2015) menyebut bahwa ada enam kunci elemen yang mempengaruhi aktivitas diplomasi. Elemen yang pertama adalah para pihak yang terlibat dalam diplomasi tidak mewakili diri mereka sendiri. Mereka terlibat dalam pekerjaan sebagai wakil negara berdaulat. Dalam penelitian ini pihak yang terlibat dalam kerja sama REDD+ Agreement adalah Indonesia dan Norwegia.

Hal ini ditunjukkan ke dalam hasil wawancara yang dilakukan dengan Kepala Sub Direktorat REDD+ Kementerian Lingkungan Hidup Indonesia (KLHK) Novia Widyaningtyas yang menegaskan bahwa "hubungan antara Indonesia dengan Norway itu sama seperti judulnya partnership, dasarnya adalah keputusan COP, dimana REDD+ itu diciptakan sebagai satu mekanisme untuk mengurangi emisi dari deforestasi yang melibatkan dua negara atau lebih, yang melakukan implementasi dan yang satunya yang memberi insentif. Jadi hubungannya adalah hubungan timbal balik, jadi menginsentif kinerja di dalam pengurangan emisi dari deforestasi dan degradasi. Mungkin itu saya rasa yang perlu ditegaskan (15/03/2018)."

Pernyataan Kepala Sub Direktorat REDD+ KLHK diperkuat oleh hasil wawancara yang dilakukan dengan Yuyun Indradi selaku Political Advisor Greenpeace. Yuyun menyatakan, "REDD+ di Indonesia dalam konteks perjanjian Indonesia dan Norwegia, merupakan perangkat yang dibuat dan dipersiapkan oleh pemerintah kedua belah negara yang berdaulat sebagai upaya pengurangan deforestasi dan emisi (03/07/2018)."

Selanjutnya, Kepala Sub Direktorat REDD+ KLHK Novia Widyaningtyas juga menyatakan bahwa "partnership REDD+ antara Indonesia-Norwegia itu berasal dari keputusan COP United Nations Climate Change Conferences (COP UNFCCC) yang terkait dengan REDD+, dimana negara maju dan berkembang harus bermitra di dalam REDD+ dan masing-masing ada bagiannya."

Berdasarkan hasil wawancara penulis terhadap para narasumber, jelas bahwa kedua negara melakukan REDD+ Agreement dalam mengurangi dampak deforestasi dan degradasi hutan, sebagai perwakilan negara yang berdaulat.

Elemen kunci diplomasi yang kedua adalah kepentingan yang diwakili. Persamaan karakteristik kedua negara yang memiliki perhatian yang cukup besar terhadap isu lingkungan hidup internasional membuat kedua negara ini melakukan kerja sama untuk melindungi lingkungan hidup, bukan untuk melakukan perdagangan karbon. Terselenggaranya kerja sama ini dilatarbelakangi oleh kedua negara yang memiliki kesadaran yang besar bahwa melindungi lingkungan hidup merupakan tanggung jawab bersama dan memiliki dampak yang sangat besar terhadap kehidupan makhluk hidup.

Meningkatnya kesadaran terhadap lingkungan hidup di masyarakat dunia juga mempengaruhi kesadaran IndonesiaNorwegia akan pentingnya lingkungan hidup. Pemerintah Indonesia-Norwegia memperkuat hubungan mereka melalui hubungan kerja sama yang dijalin. Namun tentunya, dengan disepakatinya REDD+ Agreement tentu memiliki tujuan untuk mencapai kepentingan nasional.

Indonesia menunjukkan komitmen dan kontribusinya dalam penurunan emisi gas rumah kaca yang dilakukan atas dasar sukarela (voluntary), penuh rasa tanggung jawab, dan sesuai dengan kemampuan masing-masing negara (sesuai dengan prinsip "common but differentiated responsibilities-respected capabilities/ CBDR-RC"). Indonesia kemudian juga menunjukkan peran pentingnya di tingkat dunia saat menjadi tuan rumah COP-13 tahun 2007 diselenggarakan di Bali yang diantaranya menghasilkan Bali Action Plan yang menempatkan peran penting hutan Indonesia melalui pelaksanaan skema REDD+ serta dengan dihasilkannya studi 
Indonesia Forest Climate Alliance (IFCA) (Knowledge Centre Perubahan Iklim, n.d.).

Merujuk kepada hasil wawancara yang dilakukan dengan Direktur Pembangunan Ekonomi dan Lingkungan Hidup (PELH) Kementerian Luar Negeri Republik Indonesia (Kemenlu RI) Muhsin Syihab, narasumber menyebutkan, "Pemerintah Norwegia memiliki perhatian yang besar terhadap isu-isu terkait lingkungan hidup yang tercermin dalam kebijakan politik luar negerinya. Dalam hal ini REDD+ merupakan salah satu komitmen Norwegia untuk bekerjasama dengan negara-negara pemilik hutan tropis terbesar di dunia dalam rangka mengurangi emisi gas rumah kaca yang dihasilkan dari deforestasi (05/04/2018)."

Kerja sama antara Indonesia-Norwegia adalah sebuah kerja sama yang dilakukan untuk mencapai kepentingan nasional masing-masing negara. Berdasarkan elemen diplomasi poin kedua yang sudah dijelaskan pada bagian literatur, diplomasi lingkungan hidup yang dilakukan melalui kerja sama REDD+ Agreement sudah proporsional. Berdasarkan karakteristik kedua negara, terlihat dengan jelas kepentingan nasional yang ingin dicapai oleh masing-masing negara. Kepentingan Indonesia dalam agenda REDD+ ini adalah Indonesia ingin menjaga hutan demi keberlangsungan lingkungan hidup di masa mendatang. Besarnya peran yang dimainkan dengan komitmen yang ditunjukkan, menjadikan Indonesia sebagai sebuah negara yang sangat strategis untuk dibantu oleh dunia internasional. Sementara itu, sebagai salah satu negara maju dalam penanganan isu lingkungan hidup, Norwegia mendapatkan citra yang sangat baik dengan menghabiskan tiga miliar NOK per tahun untuk pendanaan REDD+ internasional. Bantuan Norwegia yang sekaligus merupakan kewajibannya sebagai negara Annex I berdasarkan Protokol Kyoto memberikan dampak yang sangat positif untuk membangun citra positif di mata dunia.

REDD+ Agreement menguntungkan bagi kedua negara, karena adanya kerja sama ini menunjukkan bahwa negara saling memiliki ketergantungan antara yang satu dengan yang lainnya untuk mencapai kepentingan negara masing-masing. Dalam hal ini ditunjukkan oleh tanpa adanya dana bantuan Norwegia, Indonesia tidak dapat dengan mudah untuk melakukan penurunan emisi. Demikian juga Norwegia tidak akan dengan mudah mendapatkan citra baik di mata dunia jika tidak membantu Indonesia.

Elemen ketiga, kemauan dan sarana berkomunikasi. REDD+ bermula dari sebuah pencapaian yang sangat penting pada pelaksanaan COP ke-11 di Montreal pada tahun 2005. Pada saat itu, Papua bersama dengan Kosta Rika dan didukung oleh delapan anggota COP lainnya, mengajukan sebuah proposal mekanisme yang bertujuan untuk memberikan insentif bagi negara berkembang yang dapat menghindari deforestasi. Ini merupakan titik awal berkembangnya istilah RED, yaitu Reducing Emissions from Deforestation in Developing Countries. Kemudian berkembang istilah REDD (Reducing Emission from Deforestation and Forest Degradation) merupakan ide mendasar mengenai pengurangan emisi dari deforestasi dan degradasi hutan. Skema REDD memberlakukan peraturan bahwa negara-negara yang mampu mengurangi emisi dari deforestasi hutan harus diberikan kompensasi secara finansial untuk melakukan hal tersebut (Parker, Mitchel, Trivedi, \& Mardas, 2009: 14). Sejak saat Papua Nugini dan Kosta Rika menjabarkan proposal pengurangan emisi deforestasi pada COP ke-11. REDD semakin berkembang dan Tanda 'plus' I REDD+ menambahkan konservasi dan pengelolaan hutan lestari, pemulihan hutan dan penghutanan kembali, dan juga peningkatan cadangan karbon hutan. Dengan pesat REDD+ menjadi faktor yang sangat penting dalam berbagai negosiasi perubahan iklim internasional (CCMP, 2009).

Merujuk kepada hasil wawancara, Direktur PELH Kemenlu RI Muhsin Syihab menyatakan bahwa: "Pembahasan tentang REDD (yang akhirnya menjadi REDD+) telah 
dimulai sejak COP ke - 11 tahun 2005. Dalam perjalanannya, REDD berubah menjadi REDD+, yang disepakati pada COP ke-13 di Bali, Indonesia. REDD+ tidak hanya terfokus pada pengurangan emisi deforestasi, namun juga meng-address isu degradasi hutan di negara berkembang, menekankan pada pentingnya peran konservasi dan pemanfaatan hutan secara berkelanjutan, secara meningkatkan stok karbon hutan di negara berkembang" (Syihab, 2018).

Diselenggarakannya COP ke-13 di Bali menjadi wadah bagi Indonesia sebagai negara berkembang yang memiliki luas hutan hujan tropis terbesar ke-3 di dunia untuk menyuarakan aspirasinya dan mempertemukan kepentingan nasionalnya untuk menjaga hutan tropis yang memiliki pengaruh besar terhadap perubahan iklim global. Niat dari komitmen Indonesia disambut baik oleh pemerintah Norwegia dengan menandatangani nota kesepahaman Surat Niat pada 26 Mei 2010. Sehingga Bali Action Plan menjadi sarana komunikasi awal dilaksanakannya kerja sama REDD+ Agreement antara Indonesia-Norwegia.

Besarnya komitmen yang ditunjukkan oleh Indonesia dan Norwegia yang dipertemukan dalam sarana pertemuan COP membuat kedua negara ini menjalin komunikasi dan kesepakatan bersama untuk menangani permasalahan lingkungan hidup global khususnya dalam upaya penekanan gas emisi dari deforestasi dan degradasi hutan yang dihasilkan oleh Indonesia dalam REDD+ Agreement.

Elemen yang keempat yang mempengaruhi aktivitas diplomasi menurut Paul Webster Hare (2015) adalah sifat hubungan biasanya dilakukan secara terusmenerus, tidak kaku, dan membutuhkan akses sepanjang waktu. Kerja sama REDD+ yang dilakukan oleh Indonesia-Norwegia tentunya dilatarbelakangi oleh adanya kepentingan masing-masing negara yang ingin dicapai. Dengan demikian, hubungan antara Indonesia-Norwegia terus berlanjut sampai dengan masing-masing negara mencapai kepentingan negaranya.
Berdasarkan hasil wawancara, Forest Advisor at Norway Embassy Nia Irawati Murjani menyatakan bahwa: "Norway mengambil inisiatif untuk membantu tapi membantu bukan dengan upfront funding seperti umumnya donor-donor lain tapi dengan performance base payment, dalam tahapan-tahapan LoI itu intinya performance yang besarnya itu proporsi besarnya itu performance base payment, artinya kalau Indonesia tidak deliver, tidak akan mendapatkan dana bantuan (31/01/2018)".

Dukungan dana Norwegia yang disalurkan kepada Indonesia berlandaskan pada performa dan strategi yang ditempuh oleh Indonesia untuk mencapai target dilakukan secara independen, bagi manfaat Indonesia sendiri. Kerja sama IndonesiaNorwegia terdiri dari tiga fase. Pada fase pertama, dana akan digunakan untuk memfinalisasi strategi kehutanan dan iklim Indonesia dan meletakkan fondasi dasar mengenai kebijakan pendukung dan reformasi kelembagaan. Fase kedua, bertujuan untuk membuat Indonesia siap berkontribusi pada pengurangan emisi yang terverifikasi dan pada saat yang bersamaan berinisiatif untuk melakukan mitigasi dengan skala lebih besar melalui proyek percontohan di tingkat provinsi. Fase ketiga, Indonesia diharapkan sudah dapat mengimplementasikan mekanisme pengurangan emisi terverifikasi secara nasional (Knowledge Center Perubahan Iklim, n.d.).

Sampai dengan tahun 2018, setelah delapan tahun berjalannya REDD+ Agreement, Indonesia-Norwegia belum juga selesai. Forest Advisor at Norway Embassy Nia Irawati Murjani menyatakan bahwa, "Sekarang ini REDD+ berada pada Fase 1 akhir, masa transisi sebenarnya ke-2 dan ke3, jadi tidak menunggu Fase 2 selesai, (Fase) 2 dan (Fase) 3 akan berjalan beriringan. Norwegia menunggu dua perangkat untuk didirikan yaitu funding instrument dan satgas. Jika kedua perangkat tersebut tidak diselesaikan maka tidak akan bisa. Sebetulnya tergantung Indonesia sendiri, 
kalau Indonesia makin cepat makin baik, jadi komitmen yang dikatakan oleh pemerintah indonesia pada akhir tahun lalu adalah tahun ini, dan mudah-mudahan semuanya bisa selesai tahun ini."

Menurut pengamatan WALHI, skema REDD+ bukan merupakan solusi perubahan iklim karena proyek ini akan sulit dicapai, hal ini disebabkan masih banyaknya daerah yang belum mengimplementasikan skema REDD+ pada pembangunan daerahnya. Jadi, akan lebih baik jika pemerintah bekerja lebih giat lagi untuk memantau pelaksanaan REDD+ di daerah sehingga hasil dari upaya REDD+ dapat secara efektif dicapai. Namun, sisi baiknya, berdasarkan REDD+ Agreement Indonesia-Norwegia, REDD+ sebenarnya sudah harus selesai pada tahun 2016. Tetapi, muncul hambatan yang dialami Indonesia untuk memenuhi syarat yang diberikan oleh Norwegia. Kedua negara akan tetap melanjutkan kerja sama ini sampai dengan target yang disepakati tercapai. Hal ini menunjukkan bahwa kedua negara akan melanjutkan hubungan kerja sama ini walaupun terdapat berbagai hambatan dalam pencapaian target yang dituju.

Menurut Paul Webster Hare, elemen yang kelima yang mempengaruhi aktivitas diplomasi adalah isi hubungan tidak dibatasi oleh definisi universal tentang apa yang diizinkan. Masing-masing pihak mendefinisikan apa yang dilihatnya menarik untuk terlibat dalam diplomasi (Hare, 2015).

Hubungan diplomatik yang dijalin oleh Indonesia-Norwegia memperlihatkan bahwa hubungan dalam bidang lingkungan hidup memiliki dinamikanya tersendiri, hal ini dikarenakan pernah terjadi perbedaan pandangan dalam pelaksanaan REDD+. Merujuk kepada hasil wawancara. narasumber Political Advisor Greenpeace Yuyun Indradi menyebutkan, "Perbedaan pandangan terutama dalam pengelolaan dana persiapan REDD+ atau sering disebut Preparedness dan Readiness. Akhirnya dana persiapan dan kesiapan dikelola oleh UNDP, meskipun pemerintah Indonesia ingin mengelola dana tersebut sendiri (03/07/2018)."

Walaupun demikian, REDD+ yang akan selesai pada tahun 2020 akan terus dilanjutkan oleh pemerintah sampai dengan target yang sudah ditetapkan dapat dicapai. Pada saat ini, REDD+ yang seharusnya berada pada tahap pembayaran namun belum dapat dicairkan dananya karena berdasarkan hasil wawancara dengan KLHK menyebutkan bahwa pembayaran REDD+ Indonesia yang seharusnya dibayarkan pada 2017 menjadi terlambat karena ada pergantian institusi, dan itu sangat berpengaruh, namun REDD+ akan tetap dilaksanakan (Widyaningtyas, 2018). Pelaksanaan REDD+ Agreement IndonesiaNorwegia dapat dinilai sebagai sebuah kerja sama yang belum sempurna karena kedua negara pernah mengalami perbedaan pendapat dalam hal pengelolaan dana. Selain itu, Indonesia juga mengalami beberapa keterlambatan dalam memenuhi persyaratan untuk pencairan dana bantuan. Namun, hubungan kerja sama ini tetap dilanjutkan sampai dengan memenuhi target yang dituju. Norwegia tetap akan memberikan dana bantuan yang sudah disepakati jika Indonesia sudah memenuhi persyaratan yang diberikan.

Disepakatinya kerja sama REDD+ Agreement berarti Indonesia-Norwegia siap melaksanakan persyaratan-persyaratan yang telah disepakati. Indonesia akan menyelesaikan ketiga fase yang tertuang dalam surat niat dan begitu juga Norwegia memiliki kewajiban untuk mencairkan donor dana yang telah dijanjikan jika Indonesia sudah selesai melaksanakan komitmennya.

Merujuk kepada hasil wawancara dengan Direktur PELH Kemenlu RI Muhsin Syihab, REDD+ Agreement antara IndonesiaNorwegia telah berjalan cukup efektif dan akan terus dilanjutkan. Sampai saat ini telah memasuki fase transformasi (2017-2020) yang fokus pada peningkatan kapasitas, pengembangan kebijakan dan implementasi kerja. Kerja sama ini juga ditujukan untuk 
mendukung Strategi Nasional REDD+ Indonesia hingga tahun 2030. Beberapa hal yang sudah dicapai Indonesia dalam penerapan kerja sama REDD+ antara lain adalah terbentuknya kebijakan seperti pembangunan sistem registri hutan nasional, verifikasi pemetaan wilayah adat dan moratorium penggunaan lahan gambut (Syihab, 2018).

Selain itu, hasil wawancara dengan Kepala Sub Direktorat REDD+ Novia Widyaningtyas menyebutkan bahwa REDD+ Agreement antara Indonesia-Norwegia menghasilkan beberapa program seperti penegakan hukum, penanggulangan kebakaran, dan Green Village. Kemudian, Norwegia juga memberikan dukungan untuk membuat strategi nasional, beberapa national baseline, reference emission level dan beberapa dukungan terkait dengan MRV (Measurement References Verification) dan funding instrument yang juga didukung dari mereka, namun tidak semua dukungan itu berasal dari Norwegia saja karena ada juga support dari Jepang dan United Kingdom (Widyaningtyas, 2018).

Berjalannya kerja sama REDD+ telah mengantarkan Indonesia-Norwegia untuk mencapai kepentingan masing-masing negara. Indonesia dengan jumlah hutan hujan tropisnya yang luas mendapatkan bantuan dana internasional dari Norwegia atas upaya yang dilakukan untuk mengurangi emisi gas dari deforestasi dan degradasi. Berjalannya rencananya REDD+ sampai dengan tahun 2030 membuat Indonesia-Norwegia dapat melanjutkan kepentingan yang ingin dicapai. Norwegia bukan satu-satunya negara yang menjadi pendonor bagi Indonesia di bawah UN REDD+ dalam agenda REDD+, karena selain itu ada Australia, Jepang, Jerman, dan Korea Selatan (Kompas., 2011).

Namun, dengan melanjutkan kerja sama bersama Indonesia untuk menanggulangi permasalahan lingkungan hidup, citra Norwegia sebagai negara unggulan dalam isu lingkungan hidup akan semakin baik di mata dunia, karena
Norwegia mampu memelihara dengan baik hubungannya dengan Indonesia sebagai negara pendonor dalam upaya pengurangan emisi dari deforestasi dan degradasi. Dengan demikian, kepentingan yang dimiliki oleh Indonesia-Norwegia untuk melanjutkan hubungan bilateral antarnegara sudah tepat, namun ada baiknya jika ruang lingkup kerja sama bilateral antarnegara diperluas sehingga dapat memberikan mutual benefit yang lebih besar bagi kedua negara.

Elemen kunci terakhir yang mempengaruhi aktivitas diplomasi menurut Paul Webster Hare (2015) adalah semua pihak mungkin berusaha melibatkan setiap aktor dalam diplomasi mereka. Siapa yang mungkin atau mungkin bukan merupakan entitas negara atau bisa juga disebut sebagai aktor pendukung.

Untuk mendukung lancarnya kerja sama lingkungan hidup Indonesia-Norwegia melalui REDD+, terdapat beberapa aktor yang terlibat dalam kerja sama ini. Untuk memastikan bahwa roda kerja sama tetap berjalan sebagaimana yang diharapkan maka dalam kerja sama ini bukan hanya pemerintah negara Indonesia-Norwegia melainkan juga aktor non-negara yang juga merupakan aktor pendukung berjalannya kerja sama REDD+.

Merujuk kepada hasil wawancara dengan Direktur PELH Kemenlu RI Muhsin Syihab (2018), REDD+ bersifat multistakeholders yang terdiri dari perwakilan pemerintah, organisasi internasional dan pihak lainnya. Kemudian, Nita Irawati Murjani (2018), Norway Embassy, menyebutkan bahwa: "AMAN (Aliansi Masyarakat Adat Nusantara) melakukan penguatan kepada masyarakat adat, belum lagi politik-politik yang masuk itu dapat merubah tatanan sosial juga, maka dari itu harus dikuatkan kesadaran mereka untuk terus menjaga hutan, karena bagi mereka hutan itu seperti rumah."

Novia Widyaningtyas dari KLHK menyebutkan bahwa selama pelaksanaan REDD+ ada beberapa NGO yang sempat mengelola, UNDP pernah menjadi trusty 
pengelolaan REDD+. Namun, saat ini, kemitraan ditugaskan untuk melakukan kerja administrasi pengelolaan. Kemudian NGO selanjutnya yang menggantikan peran UNDP adalah Kemitraan. Kemitraan didirikan sebagai dana perwalian multidonor dan dikelola oleh UNDP. Tag-line dari Kemitraan adalah "Promoting Good Governance between State, Market and Civil Society". Kemitraan bekerja dalam tiga bidang yaitu untuk mendukung inisiatif yang berfokus pada transformasi pemerintahan dalam institusi publik, membangun kapasitas dari dalam.

Adanya aktor pendukung bukan negara membuktikan bahwa berjalannya kerjasama REDD+ tidak dapat berjalan sendirinya hanya dengan negara. Hal ini karena keterlibatan aktor pendukung seperti AMAN, UNDP, dan Kemitraan masing-masing memiliki peran untuk menjalankan roda kerjasama REDD+ antara Indonesia-Norwegia. AMAN bekerja membantu masyarakat adat untuk terus melindungi hutan alam sehingga kelestarian hutan dapat terus terjaga, karena masyarakat memiliki peran penting untuk menjaga hutan adat. UNDP membantu Indonesia dan Norwegia untuk mengelola dana bantuan yang didonorkan agar dapat dipergunakan secara bijaksana, kemudian sekarang posisi ini digantikan dengan organisasi Kemitraan yang mengurus keuangan pendanaan REDD+ antara Indonesia-Norwegia, sehingga penjelasan kunci elemen diplomasi yang sudah dijelaskan di bagian literatur poin ke-6 sudah tepat.

\section{KESIMPULAN}

Hasil penelitian menunjukkan bahwa kerja sama REDD+ Indonesia-Norwegia berjalan dengan baik atas dasar kepentingan nasional kedua negara, meski mengalami keterlambatan dalam mencapai target yang seharusnya dipenuhi pada tahun 2016. Hal ini karena Indonesia belum mampu memenuhi syarat yang diberikan Norwegia untuk mendirikan institutional set up.
Namun, Indonesia dan Norwegia tetap melanjutkan kerja sama untuk mencapai target yang telah disepakati.

Pihak yang terlibat dalam diplomasi ini adalah Indonesia-Norwegia. Indonesia memiliki peran besar terhadap perubahan iklim karena luasnya hutan tropis yang tersebar, sedangkan Norwegia sebagai negara yang pernah merasakan buruknya dampak kerusakan lingkungan hidup menyambut komitmen Indonesia dengan menandatangani perjanjian kerja sama REDD+ Agreement .

Tentunya dalam REDD+ Agreement ini terdapat kepentingan yang ingin dicapai oleh masing-masing negara. Kepentingan Indonesia dalam REDD+ Agreement adalah untuk menyelamatkan hutan. Indonesia menyadari jika hutan rusak maka seluruh dunia akan merasakan dampaknya. Sedangkan kepentingan Norwegia adalah mendapatkan citra positif sebagai yang terdepan dalam isu lingkungan hidup dengan memberikan bantuan dana kepada Indonesia. Dalam hal ini COP ke-13 di Bali dan REDD+ Agreement Indonesia-Norwegia merupakan sarana komunikasi yang digunakan untuk menyuarakan aspirasi masing-masing negara.

Dalam pelaksanaan REDD+ Agreement, Indonesia-Norwegia memiliki dinamika tersendiri karena adanya perbedaan pendapat antara pemerintah Indonesia-Norwegia terhadap pengelolaan dana bantuan. Hal itu menghambat jalannya pelaksanaan REDD+ Agreement di Indonesia. Namun, Indonesia-Norwegia tetap akan melanjutkan REDD+ Agreement sampai dengan target yang disepakati tercapai walaupun terdapat hambatan di dalam pelaksanaannya. Untuk mempermudah pelaksanaan REDD+ di Indonesia, pemerintah juga melibatkan NGO. UNDP dilibatkan untuk mengelola dana, selain itu terdapat NGO lain yang terlibat, yaitu AMAN dan Kemitraan. AMAN memiliki peran untuk memantau pelaksanaan REDD+ di Indonesia. Sedangkan, Kemitraan dilibatkan karena menggantikan peran UNDP dalam mengelola 
dana bantuan untuk menunjukkan bahwa Indonesia memiliki kemampuan untuk mengelola bantuan dana sendiri, karena disadari bahwa Kemitraan merupakan NGO dari Indonesia.

Pada titik ini, saran bagi akademis adalah melihat efektivitas diplomasi lingkungan hidup yang dilakukan oleh Indonesia-Norwegia dalam kerja sama REDD + Agreement dan melakukan penelitian

\section{DAFTAR PUSTAKA}

Hare, P. W. (2015). Making Diplomacy Work: Intelligent Innovation for the Modern World. Washington, D.C.: CQ Press.

Kemenlu RI. (2016, 31 Mei). "RI-Norwegia Perkuat Kerja Sama di Bidang Ekonomi, Lingkungan Hidup, dan HAM". Diakses dari https://www.kemlu.go.id/id/berita/ Pages/RI-\%E2\%80\%93-

NorwegiaPerkuat-Kerja-Sama-diBidang-Ekonomi,-LingkunganHidup,-danHAM-.aspx.

Knowledge Centre Perubahan Iklim. (n.d.).

"Komitmen Indonesia Dalam

Pengendalian Perubahan Iklim".

Diakses dari

http://ditjenppi.menlhk.go.id/kcpi/in dex.php/tentang/amanatperubahaniklim/komitmen-indonesia.

Kompas. (2011, 20 Mei). "Menyamakan Visi REDD+". Diakses dari https://nasional.kompas.com/read/2 011/05/20/04381565/menyamakan .visi.reddplus.

Novis, J. (2009, 24 November). "Hutan Tropis Indonesia dan Krisis Iklim". mengenai hasil implementasi REDD+ Agreement Indonesia-Norwegia. Sedangkan pada tataran praksis, saran bagi praktisi adalah mempercepat penyelesaian dan mengevaluasi efektivitas implementasi dari pelaksanaan REDD+ sehingga REDD+ Agreement Indonesia-Norwegia dapat terukur dampaknya terhadap pengurangan emisi dari deforestasi dan degradasi hutan.

\section{Diakses dari}

http://www.greenpeace.org/seasia/i d/press/reports/hutantropisindonesia-krisi-iklim/.

Parker, C., Mitchel, A., Trivedi, M., \& Mardas, N. (2009). Buku REDD+ Mini. Oxford: Global Canopy Production.

Pramudianto, A. (2011). Diplomasi Lingkungan. Jakarta: Universitas Indonesia Press.

The REDD Desk. (n.d.). "REDD in Indonesia". Diakses dari http://theredddesk.org/countries/in donesia.

Zee News India. (2014, 17 Juli). “Indonesia now country with world's highest deforestation rate". Diakses dari http://zeenews.india.com/news/econews/indonesia-now-countrywithworlds-highest-deforestationrate_948040.html.

Indradi, Y. (2018, 3 Juli). Wawancara. (Pramesthi, C. H. N., Pewawancara).

Murjani, N. I. (2018, 31 Januari). Wawancara. (Pramesthi, C. H. N., Pewawancara).

Syihab, M. (2018, 5 April). Wawancara. (Pramesthi, C. H. N., Pewawancara).

Widyanigtyas, N. (2018, 15 Maret). Wawancara. (Pramesthi, C. H. N., Pewawancara). 